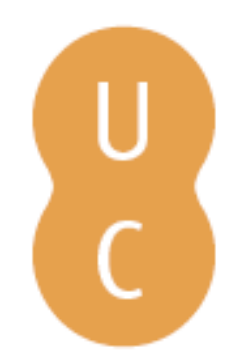

\title{
nommalina
}

\section{Plutarch's techne rhetorike for the symposium in Quaest iones Convivales: the importance of speaking well to cultivate friendship}
Autor(es):
Gonzàlez Julià, Lluís
Publicado por: Imprensa da Universidade de Coimbra; Centro de Estudos Clássicos e Humanísticos
persistente:
URI:http://hdl.handle.net/10316.2/31979
DOI:
DOI:http://dx.doi.org/10.14195/978-989-8281-17-3_6
Accessed : $\quad$ 26-Apr-2023 08:24:34

A navegação consulta e descarregamento dos títulos inseridos nas Bibliotecas Digitais UC Digitalis, UC Pombalina e UC Impactum, pressupõem a aceitação plena e sem reservas dos Termos e Condições de Uso destas Bibliotecas Digitais, disponíveis em https://digitalis.uc.pt/pt-pt/termos.

Conforme exposto nos referidos Termos e Condições de Uso, o descarregamento de títulos de acesso restrito requer uma licença válida de autorização devendo o utilizador aceder ao(s) documento(s) a partir de um endereço de IP da instituição detentora da supramencionada licença.

Ao utilizador é apenas permitido o descarregamento para uso pessoal, pelo que o emprego do(s) título(s) descarregado(s) para outro fim, designadamente comercial, carece de autorização do respetivo autor ou editor da obra.

Na medida em que todas as obras da UC Digitalis se encontram protegidas pelo Código do Direito de Autor e Direitos Conexos e demais legislação aplicável, toda a cópia, parcial ou total, deste documento, nos casos em que é legalmente admitida, deverá conter ou fazer-se acompanhar por este aviso.

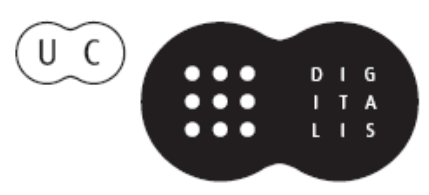




\section{Symposion and Philanthropia in Plutarch}

\section{José Ribeiro Ferreira, Delfim Leão Manuel Troster e Paula Barata Dias (eds.)}

IMPRENSA DA UNIVERSIDADE DE COIMBRA 


\title{
Plutarch's TeChNE RHETORIKE FOR THE SYMPOSIUM IN QUAESTIONES CONVIVALES: THE IMPORTANCE OF SPEAKING WELL TO CULTIVATE FRIENDSHIP
}

Llứs GonZÀLEZ Julià

University of Barcelona

\begin{abstract}
This paper discusses the advice on rhetorical matters that Plutarch gives in the Quaestiones Convivales to stress the importance of good conversational skills in establishing fruitful relationships with other people during after-dinner table talk. Reflecting the association between education and the symposiac context under the Roman Empire, Plutarch suggests procedures for choosing and discussing the best themes for conversation, and for interacting in an appropriate manner with the other guests. Rhetoric thus takes up a central position in situations in which friendships may be made or strengthened.
\end{abstract}

The banquet in Ancient Greece was one of the favourite occasions for the transmission of values and knowledge. The conversations held after the meal, accompanied by wine - the final part of the gathering, known as the symposion - ranged over the most topical themes of the moment and helped their participants to build up links of friendship based on common interests and beliefs. Praise for bravery and youth centred the conversation in the circles of Callinus and Tyrtaeus, while slightly later, Alcaeus and Theognis celebrated the membership of a political faction which trained the young in the traditional values that they will need to perpetuate their status. Plato described another kind of banquet that emerged during the Classical Era, a banquet where the philosophical conversation of the most distinguished citizens helped the guests to understand the world around them. In the Empire, the banquet was retained as a space for encouraging fellowship and the exchange of ideas. However, as befitted the times of the Second Sophistic, the subjects addressed were more trivial: the pepaideumenoi, cultivated men educated in the system of the egkyklios paideia, showed off their knowledge in erudite debates in which every participant could learn something new regarding the theme under discussions ${ }^{1}$.

Rhetoric was also a fundamental ability for those cultivated men seeking to hold interesting table talks with their friends. After several centuries in which the dedication to laudatory and deliberative rhetoric predominated, in the Empire the importance of forensic rhetoric gradually increased ${ }^{2}$. A rhetor of the Second Sophistic would not only have trained pupils for careers in political councils or the courts where they would make declamations or representations in front of auditoria, but would also have had pupils who did

\footnotetext{
${ }^{1}$ F. Pordomingo Pardo, 1999 stresses the literary character of the banquets of the Empire, and E. SuÁrez de LA Torre, 2005, pp. 472-9 places Plutarch's symposia inside the environment of academic and cultural circles.

${ }^{2}$ Plutarch $(Q C$ IX 14.3, 744d) considers this form of rhetoric to be the first to have developed.
} 
not wish to devote themselves professionally to sophistry but were interested in learning the ways of good speaking for its own sake ${ }^{3}$. At school, then, pupils studied everyday situations in which an educated man could gain distinction by demonstrating his oratory skills. Weddings, births, anniversaries, farewells or funerals were occasions for showing one's knowledge of oratory and rhetoric. In the classroom, teachers used small manuals which described the most appropriate themes for each occasion and how they should be presented. In the Techne rhetorike (attributed to Dionysius of Halicarnassus, but thought to date from the third century $\mathrm{AD}^{4}$ ) are seven examples of these manuals, known as $\mu \varepsilon \dot{\varepsilon} \theta 0 \delta o 1$; they advise that speeches to celebrate births should begin by mentioning the day the subject was born, the time of year, and the place, and then should speak of the qualities of the newborn and prophesize a promising future (D. H., Rh. III) $)^{5}$. Likewise, even if not in a systematic way, but rather by means of interspersed comments often found in the prefaces, or in the form of personal observations during the discussions between the guests, Plutarch establishes in Quaestiones Convivales ( $Q C$ hereafter) a theory of rhetoric for speeches and conversations at banquets, which would not have been out of place in any rhetorical handbook of his time.

Rhetoric was the third and last stage in the Graeco-Roman educational system and completed the acquisition of knowledge of cultivated people. In parallel to its technical specificity, the learned men belonging to educated circles such as Plutarch's, found in the teachings of rhetors the essential elements of their culture. "Matière de base de la paideia, la rhétorique ne cessait de fournir des cadres de pensée aux pepaideumenoi" ${ }^{7}$, and, therefore, rhetoric was not excluded from their table talks, as well as they discussed many other subjects from the other two previous educational levels. Certainly, Plutarch's $Q C$ contains many passages that deal with the subjects of the first stages of the education given to the young of the Empire ${ }^{8}$. For instance, some questions discuss the nature of the letters of the alphabet: one discussion enquires about the numerical proportion between the quantity of vowels and semivowels ( $Q C$ IX $3,738 c-739 a)$, and another why the alpha is placed first among the letters (QCIX 2,737c-738c). Plutarch clarifies

${ }^{3}$ T. Whitmarsh, 2001, p. 5 describes a society that marked its prestige in terms of its knowledge and immersion in the Greek paideia, not only among those who devoted themselves actively to literature but also in society in general.

${ }^{4}$ Cf. G. Kennedy, 1972, p. 320 and A. Manieri, 2005, p. 18 for the attribution and the date of composition of the work.

${ }^{5}$ In spite of this ancient interest in speeches delivered in private occasions, there is not any extant treatise on the rhetoric of conversations; $c f$. L. PERnot, 1993b for a reflection about the lack of a conversational theory in rhetorical texts,

${ }^{6}$ The theory and practice of rhetoric in other treatises by Plutarch have been studied in depth in the collective volume of L. Van der Stockt, 2000 and in H. M. Martin JR., 2001. Specific studies of the theme in the $Q G$ are G. Matino, 1991 and S.-T. Teodorsson, 1996.

${ }^{7}$ F. Frazier, 2000b, pp.188-89.

${ }^{8}$ H. I. Marrou, 1948, pp. 389-421 and R. Cribiore, 2001, pp. 160-245 describe a threestage educational process in which the young learnt to read and write with the grammatistes, studied and discussed literary authors with the grammatikos, and practised techniques of composition with the rhetor. 
that the answer proposed by Hermeias was the stock reason given in the schools ( $Q C$ IX 2.2,737e).Words, and especially their use and their etymology, constitute an object of discussion in their own right. Among the numerous examples we find throughout the nine books, two cases apply directly to the context of the symposium. First, Lamprias defends the etymology of the term

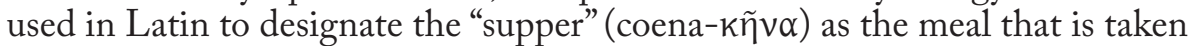
along with friends, thus deriving from the word kolvwvía ("fellowship") ( $Q C$ VIII $6.5,726 \mathrm{e})^{9}$. The second example is a question that debates the meaning

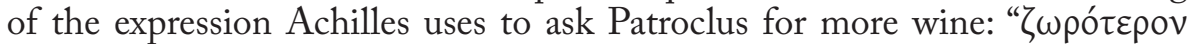

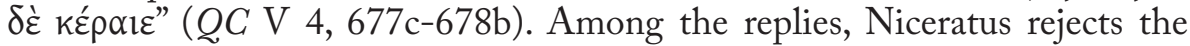
traditional interpretation of "unmixed" for the term $\zeta \omega \rho o ́ \varsigma$ and proposes the

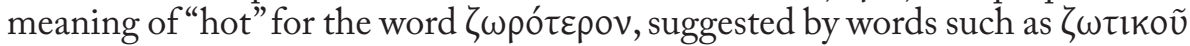

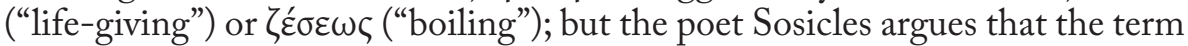
means "well-mixed", given the relation between the expression and a sentence in Empedocles.

In the schools of the grammarians, the verses of the poets were discussed and interpreted exhaustively in order to teach the pupils their meaning and the methods of expression they used. Indeed, the commentary of literary passages (especially texts by Homer) was an endless source of themes for after-dinner table-talk. The $Q C$ presents many examples in which the diners debate matters such as why the poet used a particular epithet for each particular liquid, but called oil only liquid ( $Q C$ VI 9, 695e-696d), or which of Aphrodite's hands Diomedes wounded ( $Q C I X 4,739 a-d)$. Literary quotation $s^{10}$ are found throughout the discussions, and are mostly from authors who made up the core of the school syllabus ${ }^{11}$. On one occasion Plutarch himself states that some of the issues that come up in the discussions of the literary passages, such as the question of the antinomy of the third book of the Iliad, should be studied by rhetoricians, who are well skilled in this field ( $Q C$ IX $13.1742 \mathrm{a}-\mathrm{b}$ ). So rhetoric was of considerable importance in the banquet context; it served not only to resolve doubts presented in trivial questions, but had a key role in ensuring that diners could enjoy the company and the conversation to the full. Ammonius ${ }^{12}$ claims that everybody needs culture and speeches ( $Q C$ IX 14.2, 743e-f), just after Herodes the

${ }^{9}$ Cf. M. Cerezo, 1986 and B. Rochette, 1997, pp. 239-41 for an outline of Plutarch's use of Greek and Latin. B. RochetTe, 1997, p. 261 specifically studies the discussion of the etymology of $\kappa \tilde{\eta} v \alpha$.

${ }^{10}$ The use of literary quotations in speeches was a demonstration of the speaker's learning and erudition, but they were also an important rhetorical device that could enhance the speech's

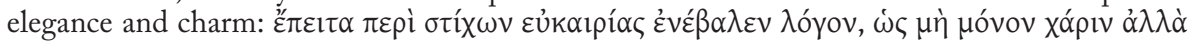

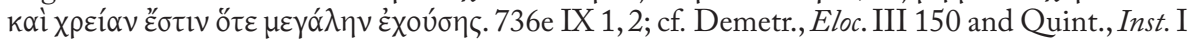
6.39. For a discussion of the use of quotations from Homer in Plutarch, see J. M. Díaz Lavado, 1994 and I. Sluiter, 2004-2005.

${ }^{11}$ T. Morgan, 1998 analyses the content, number, and importance of the literary texts used in the schools of the Empire.

${ }_{12}$ Ammonius had organized a banquet for some teachers to celebrate the end of the exams at the Diogeneion; there they talked about the appropriate occasion to quote ancient books ( $Q C$ IX 1.1, 736d), which shows a close relation between education and some banquets. 
rhetor has praised the function of rhetoric in conversation, attributing to rhetoric the same importance in conversation as it has in front of the jury or in deliberations (IX 14.1, 743d).

For Herodes, the ideal diner was a good ó $\mu \imath \lambda \eta \tau \imath k o ́ s$, a person able to speak well when attending an "entretien" ${ }^{13}$. Throughout the $Q C$, the success of a banquet depends not so much on the food served but on the conversation and the company. Plutarch tells Sosius Senecio of a comment once made by an amiable man:

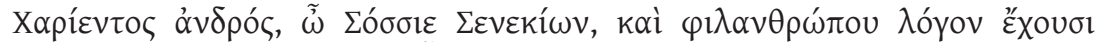

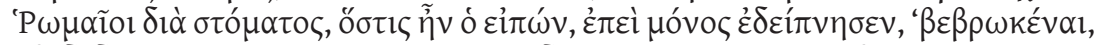

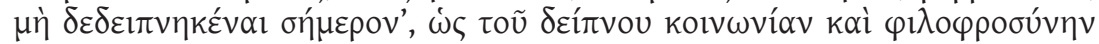

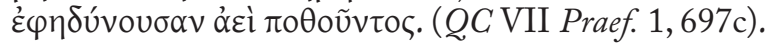

The Romans, Sossius Senecio, are fond of quoting a witty and sociable person who said, after a solitary meal, 'I have eaten, but not dined to-day,' implying that a 'dinner' always requires friendly sociability for seasoning. ${ }^{14}$

For this man, the banquet context always represented tolerance and cordiality. Plutarch also explains that the most important aspect of the banquet is the presence of a friend, family member or acquaintance - not to eat and drink with us, but to take part in the give-and-take of conversation ( $Q C \mathrm{VII}$, Praef., $1,697 \mathrm{~d})^{15}$. In fact, the first of the questions posed in the second book tries to establish whether it is better for the food at a banquet to be served to each guest or on common trays from which each guest should serve himself ( $Q C$ II 10, 642e-644e). Hagias favours the use of common trays, since, in his view, the banquet is an occasion that invites the company to general fellowship ( $Q C$ II 10.1, 642f-643a), manifested not only in sharing a common meal but also in singing, entertainments and conversation (QC II 10.1, 643b). Conversation is the sustenance that feeds the soul once the body has had its fill of food and drink (QCV Praef., 1, 673a); men of wit and taste devote themselves to it and feed the soul once they have eaten, in order to enjoy the pleasure that derives from talk (QC V Praef., 1, 672e).

So it is not only the body that should be satisfied at the banquet. Guests come to share not only meat, wine and dessert, but also entertainments such as conversation and the amiability that leads to friendship (QC IV Praef., 660b). For Dicaearchus, it is important to obtain the empathy of all, especially that of well-bred people; the banquet is a better setting than the market place - a place where people go to discuss their business - since people normally attend parties in order to make new friends or to give a good time to the old ( $Q C$ IV Praef., 659e-660a). Dicaearchus is not alone; significantly, in the preface to the

${ }^{13}$ Cf. L. Pernot, 1993b, pp. 428-29.

${ }^{14}$ Translation taken from E. L. Minar ET AL., 1961, p. 5.

15 P. A. Stadter, 1999 stresses the importance of conversation in the banquet, which Plutarch compares with the enjoyment of fine food (see also L. Romeri, 2002, pp. 183-9). 
first book Plutarch repeats the common belief that eating together encourages friendship (QC I Praef., 612d) ${ }^{16}$. Later, one of the norms established for the celebration of the banquet is the prohibition of doing or saying anything that may impede its principal function: that is, to heighten fellowship, or to engender it through pleasure ( $Q C$ I $4.3,621 \mathrm{c})$. At a banquet it is better to run

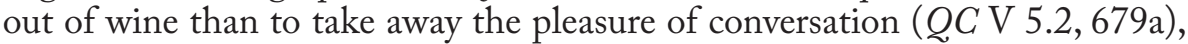
because this would imply the division of the party into separate groups and would destroy the idea of community ( $Q C V$ V 5.2, 679b). Alexander the Great, whose deeds and sayings acquired the category of chreiai ${ }^{17}$ in the Empire, is also praised in the $Q C$ as a model of a wise man who spent a great deal of time in banquets, but drank little, preferring to spend his time conversing talking with friends $(Q C \text { I } 6.1,623 \mathrm{~d})^{18}$.

But, how should these conversations technically be according to Plutarch? The first question of the first book seems to be a declaration of intentions, as Plutarch sets out the types of theme that are suitable for table talk ( $Q C$ I 1.4, $614 \mathrm{a}-\mathrm{b})$. He also summarizes them in the preface to the fifth book ( $Q C \mathrm{~V}$ Praef. 1,673a). In general, they are themes taken from history or from everyday life, which allow reflections on life itself, history, or unusual subjects. Among the questions discussed in the $Q C$ are the appropriateness of talking about politics ( $Q C$ VII 9, 714a-d and $Q C$ VII 10, 714d-716c) or about philosophy ( $Q C$ I 1, 612e-615c). Politics and philosophy, it is concluded, have their place at the banquet, providing they do not interfere with the main object of the occasion $^{19}$. Philosophical themes should be sought that do not cause angry confrontations or are so difficult or technical that non-specialists are unable to take part in the conversation ${ }^{20}$ and begin singing or telling foolish stories ( $Q C$ I 1.5, 614f-615a). Plutarch concludes that pedantry has no place at the banquet ( $Q C \mathrm{I} 1.5,615 \mathrm{~b})$. All the diners must be included and, whether or not they speak, must feel that they are participants in the conversation $(Q C \mathrm{VI}$ Praef. 1, 686c). This is the basic norm for the choice of a theme at a banquet (QC VII Praef., 697e).

"What, according to Xenophon, are the most agreeable questions and jokes to make at table?" (QCII 1,629d-634f) is the first question of the second book: the answer is not very different to the one Plutarch gives for philosophy:

${ }^{16}$ Plutarch represents friendship as one of the most important elements of society. The multiple ways of representing and denoting it, both in the Lives and in the Moralia, have been discussed by M. Cerezo, 1997, pp. 110-22; R. Giannattasio Andria, 2000; M. L. Desclos, 2001; R. M. Aguilar, 2002 and S.-T. Teodorsson, 2007.

17 A chreia was an example of the words or deeds of a famous person which generally contained a pedagogical or moral element. cf. R. CRIBIORE, 2001,pp. 223-5 and R. Webi, 2001, pp. 294-6 on their rhetorical use as progymnasmata at school.

${ }^{18}$ Cf. the contribution of P. Gómez \& M. Mestre in this volume and T. Whitmarsh, 2002, pp. 182-3, on the use of the figure of Alexander in the banquet.

${ }^{19}$ For an analysis of the themes addressed in the $Q C$ see E. SuÁrez DE LA Torre, 2005, pp. 476-9 and F. Martín García, 1987, p. 26. S.-T. Teodorsson, 1995 specifically analyses the inclusion of politics in the $Q C$.

${ }^{20}$ For this precise reason, Plutarch cannot include any systematical treatment of the rhetorical theory in $Q C$, and has to spread his opinions in several passages. 
the most agreeable questions are the ones that are accessible to the greatest number of the guests ( $Q C$ I 1.5, 614e). They should be simple, easy to answer, and must deal with singular themes:

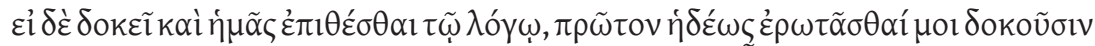

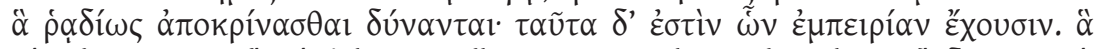

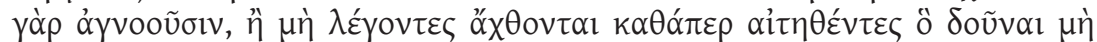

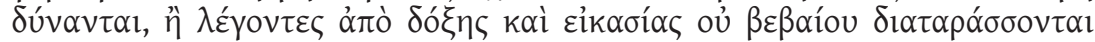

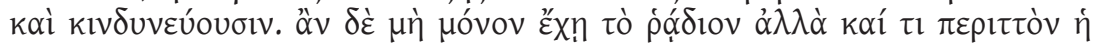

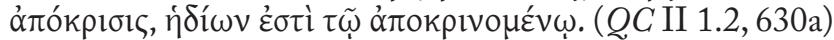

And yet if it is decided that we too apply ourselves to the problem, it seems to me, in the first place, that men are glad to be asked what they are able to answer easily, that is, questions about matters in which they have experience; for about what they do not know, either they say nothing and are chagrined as though asked for what they cannot give or they reply with a guess and an uncertain conjecture and so find themselves in a distressing and dangerous situation. However, if the answer is not only easy but somehow striking, it is more agreeable to the answerer ${ }^{21}$.

It is important to ask about things that one's interlocutor will be pleased to answer ( $Q C$ II 1.2, 630c); one should not ask about wrongs or misfortune suffered ( $Q C$ II $1.3,630 \mathrm{e}$ ), but should encourage people to speak about their successes ( $Q C$ II 1.3, 630f-631a). Similarly, the questions should not lead to conflict; they should elicit not anger or envy among the diners, but goodwill ( $Q C$ II 1.3, 631b). However, care is required with conversations that might contain praise $\mathrm{e}^{22}$. It is important that the host should not drink to one guest before another ( $Q C \mathrm{I}$ 2.2,616b), since this may arouse envy and jealousy ( $Q C \mathrm{I}$ $2.3,616 \mathrm{e})$. And above all one must avoid praising oneself, as the company may be irritated by the speaker's vainglory ( $Q C$ II $1.2,630 \mathrm{~d}$ ).

So, as well as determining which themes are acceptable at a banquet, another point should be considered before starting to speak: one must bear in mind who is present $(Q C \mathrm{I} 1.3,613 \mathrm{~d})^{23}$. If the philosopher (or, by extension, any speaker) sees that his dining companions are not interested in his words, he should change his tone and his subject, in order to follow the others and find pleasure in their entertainments $(Q C$ I $1.3,613 \mathrm{f})$. An awareness of the right

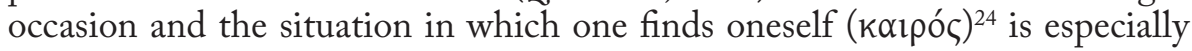

${ }^{21}$ Translation taken from P. A. Clement \& H. B. Hoffleit, 1969, p. 111.

${ }^{22}$ L. Pernot, 1993a, lists all the aspects that regulated the techniques of composing and delivering speeches of praise. Despite dealing with epideictic oratory, they can be applied as well to praises in conversations.

${ }^{23}$ Knowing the audience to which one addresses a speech was a basic norm for the orators in courtrooms and tribunals; by adapting their words to the occasion, their speech could achieve its objective, according to Quint., Inst. XI 1.43.

${ }^{24}$ Appropriateness is one of the basic virtues of the orator. A speech should be delivered in the right place, at the right moment and in the right manner; cf. Arist., $R b$. III 7 1408a-b and Quint., Inst. XI 1.1. 
important to avoid errors when speaking ( $Q C$ I 1.1, 613a). As Simonides says to one of his interlocutors who remained silent, it may even be preferable to say nothing if one runs the risk of saying something inappropriate:

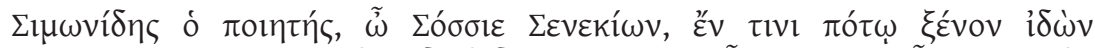

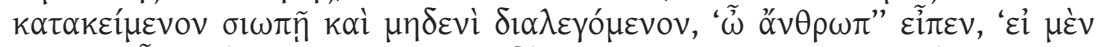

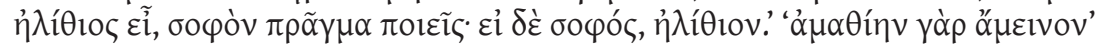

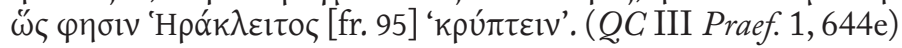

When the poet Simonides at some drinking-party, my dear Sossius Senecio, saw a guest sitting in silence and holding no conversation with anyone, he said, 'Sir, if you are a fool, you are doing a wise thing; but if wise, a foolish thing.' As Heraclitus remarks, 'it is containly better to conceal ignorance ${ }^{25}$.

When one is ready to speak and is sure that the inuentio ${ }^{26}$ is correct, the elocutio ${ }^{27}$ of the speech must also conform to certain basic precepts. In the fourth question of the first book, Plutarch examines the qualities of the ideal director of the feast. One of them is the ability to give brief and concise instructions (QC I 4.1, 620b). In fact, brevitas/ $\beta \rho \alpha \chi u ́ \tau \eta \varsigma^{28}$ is one of characteristics stressed most by treatises on rhetoric. It is required especially in the narrations of events and the presentation of arguments: in the first case, so that the explanations should not be excessively long and the thread of the story be lost, and in the second, so that the presentation should be energetic, vigorous, clear, and direct. Although Plutarch does not mention the point explicitly, his reproduction of the conversation of his dining companions suggests that the most important features of their interventions are moderation and brevity. This brevity should not be considered as a lack of expressiveness, but as the need to avoid superfluity or irrelevance to the theme under discussion ${ }^{29}$ and to make sure that a single speaker should not turn the conversation into a monologue and thus defeat the point of the banquet. In the arguments presented during the symposiac gathering, Plutarch also recommends that speakers try to persuade their audiences rather than to demonstrate things to them; they should reserve the use of methods such as enthymemes or syllogisms ${ }^{30}$ for situations that require a more energetic and direct type of argumentation ( $Q C$ I 1.4, 614c).

${ }^{25}$ Translation taken from P. A. Clement \& H. B. Hoffleit, 1969, p. 199.

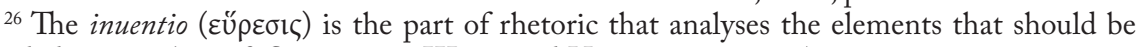
included in speeches; cf. Quint., Inst. III 3.1 and Hermog., Inv. 1.65.

${ }^{27}$ The elocutio $(\lambda \dot{\varepsilon} \xi 1 \varsigma)$ is the part of rhetoric that analyses how the thought and ideas in the speech are expressed in language; cf. Arist., Rh. III 1 1403b, Quint., Inst.VIII 1.1.

${ }^{28}$ Brevity is one of the main virtues of speeches in the simple style; cf. Demetr., Eloc. IV 197-198, Cic., Inv. 1.28 and Quint., Inst. IV 2.31.

${ }^{29}$ Quint., Inst. IV 2.42 notes that brevity does not imply speaking little, but that the speech should not last longer than is strictly necessary. However, excessive brevity is considered an error: the speaker may leave out important details.

${ }^{30}$ Enthymemes and syllogisms are variations on the method of argumentation which proceeds from deductions made on the basis of logical and dialectical premises and conclusions; cf. Arist., Rh. I 2 1356a-b and Quint., Inst.V 14.5. 
Menander, whose works were among the main instruments used to teach Greek to schoolchildren, was a model for the ideal style that should be used in the speeches and his works were appropriate at the banquet as well ( $Q C$ VII 8.3, $712 \mathrm{~b}$ ). This seems to mean that the style of a table talk must be agreeable and simple ${ }^{31}$, without great ornamentation or metrical rhythms more characteristic of grander occasions, and must use simple, sensible sentences. And finally, to heighten the pleasure, seriousness and light-heartedness should be combined ${ }^{32}$, as Plutarch notes in other passages (QC I 4.3,621d). The place of jokes at the banquet is discussed in detail in the $Q C$, though the instructions given concerning their use are the same as those that refer to serious interventions $s^{33}$. One should only use jokes that give pleasure. Just as one should be aware of the aptness of what one is about to say, one should consider whether it is better to make the joke or to remain silent ( $Q C$ II $1.4,631 \mathrm{c}$ ); one must be alert to the opportune moment ( $Q C$ II 1.10, 633e). A successful joke is one that emerges naturally from the conversation, one that has an unaffected tone, and does not appear to be premeditated or forced ( $Q C$ II $2.13,634 \mathrm{~d}-\mathrm{e}$ ). In summary, then, jokes should be used with discretion, in the same way as good sense is applied to avoid problems in other situations such as the market place, the arena, or the courtroom ( $Q C$ I 5.2, 622b).

The harmony of the meeting will be maintained if all these rules of protocol are followed. However, the director of the feast must know what to do and what to say on occasions in which this harmony is threatened. The main dangers that the host may face are disputes between his fellow diners and the excesses caused by wine. Some, who have little interest in maintaining friendship, raise topics of conversation that may bring to light the imperfections in the character of the others (QC III Praef. 2, 645b). Quite often diners may argue with each other, or with a servant or with the host himself. This situation is unbecoming among friends and in the banquet context ( $Q C$ II $10.2,644 a)^{34}$. So the host should be careful to seat the guests at table in such a way as to reduce rivalries as far as possible; difficult guests should be kept apart so as to avoid fights between poets and sophists (QC I 2.6, 618e) or teachers (QC IX 1.1, 736e). In general, then, the host must also create a cordial atmosphere among the diners to avoid situations of tension ( $Q C$ I 4.2, 621a). Wine is an excellent instrument for helping people to relax, to speak to the other guests and to strike up friendships (QCIV Praef., 660c) $)^{35}$; but excess may lead to inappropriate behaviour and may

${ }^{31}$ For Dionysius of Halicarnassus (D. H., Th. 48) the skill in the application of the virtues of expression should be present both in courtrooms and tribunals and in conversations between friends.

${ }^{32}$ The importance of laughter as a fundamental part of the banquet and as a counterpoint to the seriousness of philosophical conversations has been stressed by P. GómEz \& M. Juf REsA, 1999 and F. Frazier, 2000a, pp. 487-9.

${ }^{33}$ Cf. M. A. Bellu, 2007 for a detailed study of the conception of jokes in Plutarch's QC.

${ }^{34}$ P. Gómez, (in press), analyses the vision given by Lucian, in the Symposium or the Lapiths, of a banquet disrupted by the fights between sophists and philosophers caused by excessive drinking.

${ }^{35}$ As explained by L. Romeri, 2002, pp.172-6, S.-T.Teodorsson, 1999 and F. B. Titchener, 
cause men to chatter about matters that should remain concealed (QCIII Praef. 2,645 b). Excessive drinking also reduces the ability to speak correctly ( $Q C$ III $5.2,652 \mathrm{~d})^{36}$, a skill that is of vital importance to the success of the banquet. Indeed, there is nothing more imprudent or out-of-place than a conversation produced by excessive drinking ( $Q C$ VIII Praef., 716e $)^{37}$. Finally, if nothing can be done to resolve a conflict or to calm a squabble more typical of the market place than of a feast, the discussion should stop and make way for musical entertainment ( $Q C$ VII 8.4,713e-f). But music should not be introduced if it is unnecessary: the diners should take their main pleasure from conversation $(Q C$ VII 8.4,713d), because conversation should be the centre of the banquet at all times ( $Q C$ VII 8.4, 713b-c).

So appropriate conversation helps to create a congenial atmosphere and to establish bonds of empathy and fellowship feeling between the guests. Talk is the most important element of the banquet, its foundation. As a rhetor would have done, Plutarch details the themes that should be discussed at banquets, how one should speak and even what one should do if the conversation flags. Though scattered throughout the $Q C$ rather than brought together in a cohesive whole, Plutarch's descriptions are sufficient to show the reader that even at the dinner table, an intimate and relaxed meeting, the techne rhetorike help guests to participate in a suitable manner in the conversation and help them to make and maintain friendships.

\section{WORKS CITED}

Aguilar, R. M., "La amistad según Plutarco: los Moralia", in L. Torraca (ed.), Scritti in onore di Italo Gallo, Napoli, 2002, pp. 7-26.

Bellu,M.A.,"Amor hacia el prójimo: el difícil arte de la broma según Plutarco", in J. M. Nieto Ibáñez (ed.), El amor en Plutarco. Actas IX Simposio Internacional de la Sociedad Española de Plutarquistas (León, 28-30 de Septiembre de 2006), León, 2007, pp. 105-12.

Calderón Dorda, E., "El léxico de la embriaguez en Plutarco," in A. Pérez Jiménez, \& F. Casadesús Bordoy (eds.), Estudios Sobre Plutarco Misticismo y Religiones Mistéricas en la Obra de Plutarco. Actas del VII Simposio Español sobre Plutarco. (Palma de Mallorca, 2-4 de Noviembre, 2000), Madrid, 2001, pp. 473-82.

Cerezo, M., "Plutarco en la encrucijada lingüística greco-romana", Scriptura, 2 (1986), pp. 117-23.

1999, wine occupies a key function in the banquet, as the name sym-posion itself shows; in moderate amounts, it animates diners and helps them to participate actively in conversation.

${ }^{36}$ Quint., Inst. XI Praef., 1 identifies the effects of wine on the ability to speak as poor pronunciation, a mannered air, tomfoolery, or the trembling characteristic of old age.

${ }^{37}$ The vocabulary that Plutarch uses to denote excessive drinking and its consequences for the drinker is the key feature of the study of E. Calderón Dorda, 2001. 
Plutarco. Virtudes y vicios de sus héroes biográficos, Lleida, 1997.

Clement, P. A. \& Hoffleit, H. B., Plutarch's Moralia, VIII, Cambridge, Mass., 1969.

Cribiore, R., Gymnastics of the mind: Greek Education in Hellenistic and Roman Egypt, Princeton, 2001.

Desclos, M. L., "Amis/amitié”, in F. Hartog (ed.), Plutarque. Vies parallèles, Paris, 2001, pp. 1952-4.

Díaz Lavado, J. M., “Tipología y función de las citas homéricas en el De audiendis poetis de Plutarco", in M. García VAldÉs (ed.), Estudios sobre Plutarco: ideas religiosas. Actas del III Simposio Español sobre Plutarco, Madrid, 1994, pp. 681-96.

Fernández Delgado, J. A., "El sentido del humor de Plutarco", in J. A. Fernández Delgado \& F. Pordomingo Pardo (eds.), Estudios sobre Plutarco: Aspectos Formales. Actas del IV Simposio Español sobre Plutarco (Salamanca, 26-28, Mayo, 1994), Madrid, 1996, pp. 381404.

Frazier, F. (a), "Rires et rieurs dans l'oeuvre de Plutarque", in M. L. Desclos (ed.), Le Rire des Grecs. Anthropologie du rire en Grèce ancienne, Grenoble, 2000, pp. 469-94.

(b), "La rhétorique contemporaine sous le regard de Plutarque", in L. VAn Der StockT (ed.), Rhetorical Theory and Praxis in Plutarch. Acta of the IVth International Congress of the International Plutarch Society (Leuven, July 3-6, 1996), Louvain, Namur, 2000, pp. 183-202.

Giannattasio Andria, R., "La parole dell'amicizia. Prassi retorica nel De amicorum multitudine", in L. VAN DER STOcкт (ed.), Rhetorical Theory and Praxis in Plutarch. Acta of the IVth International Congress of the International Plutarch Society (Leuven, July 3-6, 1996), Louvain, Namur, 2000, pp. 225-36.

Gómez, P., "Llucià a taula: aliments i simposi", in F. Mestre et Al. (eds.), Llucià de Samòsata: escriptor grec i ciutadà romà, Barcelona (in press).

Gómez, P. \& Jufresa, M., "La risa y el vino en los escritos simposíacos de Plutarco", in J. G. Montes Cala et al. (eds.), Plutarco, Dioniso y El Vino. Actas del VI Simposio Español Sobre Plutarco (Cádiz, 14-16 de Mayo, 1998), Madrid, 1999, pp. 255-68.

Kennedy, G., The Art of Rhetoric in the Roman World, Princeton, 1972.

Manieri, A., I discorsi per le feste e per i giochi (Ars Rhet. I et VI Us.- Rad.), Roma, 2005.

Marrou, H. I., Histoire de l'éducation dans l'antiquité, Paris, 1948. 
Martin Jr., H. M., "Plutarch", in S. E. Porter (ed.), Handbook of Classical Rhetoric in the Hellenistic Period (300 B.C.-A.D. 400), Leiden, 2001, pp. 715-36.

Martín García, F., Plutarco. Obras morales y de costumbres IV. Charlas de sobremesa, Madrid, 1987.

Matino, G., "Strutture retoriche e colloquiali nelle Quaestiones convivales", in G. D'Ippolito, \& I. Gallo (eds.), Strutture Formali Dei Moralia Di Plutarco. Atti del III Convegno Plutarcheo (Palermo, 3-5 Maggio, 1989), Napoli, 1991, pp. 295-314.

Minar, E. L. ET Al., Plutarch's Moralia, IX, Cambridge, Mass., 1961.

Morgan, T., Literate Education in the Hellenistic and Roman worlds, Cambridge, 1998.

Pernot, L. (a), La rhétorique de léloge dans le monde gréco-romain, Paris, 1993. (b), "Un rendez-vous manqué", in L. Pernot, Rhétoriques de la conversation, de l'Antiquité a l'époque moderne, Rhetorica XI.4, 1993, pp. 421-437.

Pordomingo Pardo, F., "El banquete de Plutarco: ¿ficción literaria o realidad histórica?", in J. G. Montes Cala et al. (eds.), Plutarco, Dioniso y El Vino. Actas de VI Simposio Español Sobre Plutarco (Cádiz, 14-16 de Mayo, 1998), Madrid, 1999, pp. 379-92.

Rochette, B., Le latin dans le monde grec, Bruxelles, 1997.

Romeri, L., Philosophes entre mots et mets: Plutarque, Lucien, Athénée autour de la table de Platon, Grenoble, 2002.

Sluiter, I., "Homer in the dining room: an ancient rhetorical interpretation of the duel between Paris and Menelaus (Plu., Quaest. conv. 9, 13)", CW, 5984 (2004-2005), pp. 379-96.

Stadter, P. A., "Drinking, Table Talk, and Plutarch's Contemporaries", in J. G. Montes Cala et al. (eds.), Plutarco, Dioniso y El Vino. Actas del VI Simposio Español sobre Plutarco (Cádiz, 14-16 de Mayo, 1998), Madrid, 1999, pp. 481-90.

Suárez de la Torre, E., "Diálogo, filosofía y simposio en Plutarco", in M. Jufresa et Al. (eds.), Plutarc a la seva època: Paideia $i$ societat. Actas del VIII Simposio Internacional de la Sociedad Española de Plutarquistas (Barcelona, 6-8 de Noviembre, 2003), Barcelona, 2005, pp. 463-84.

Teodorsson, S.-T., "La politica nelle Questioni conviviali", in I. Gallo \& B. Scardigli (eds.), Teoria e Prassi Politica nelle Opere di Plutarco. Atti del V Convegno plutarcheo (Certosa di Pontignano, 7-9 Giugno, 1993), Napoli, 1995, pp. 433-8. 
"Principles of composition in the Quaestiones Convivales", in J. A. Fernández Delgado \& F. Pordomingo Pardo (eds.), Estudios sobre Plutarco: Aspectos Formales. Actas del IV Simposio Español sobre Plutarco (Salamanca, 26-28 de Mayo, 1994), Madrid, 1996, pp. 39-48.

"Dionysus moderated and calmed: Plutarch on the connvival wine", in J. G. Montes Cala et al. (eds.), Plutarco, Dioniso y El Vino. Actas del VI Simposio Español sobre Plutarco (Cádiz, 14-16 de Mayo, 1998), Madrid, 1999, pp. 57-69.

"Four terms of friendly emotion in Plutarch: $\varphi \imath \lambda \alpha v \theta \rho \omega \pi i ́ \alpha, \varphi \imath \lambda i ́ \alpha$, है $\rho \omega \varsigma$,

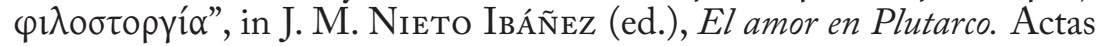
IX Simposio Internacional de la Sociedad Española de Plutarquistas (León, 28-30 de Septiembre, 2006), León, 2007, pp. 209-19.

Titchener, F. B., "Everything to do with Dionysus: banquets in Plutarch's 'Lives", in VAN DER Stockt, L. (ed.), Rhetorical Theory and Praxis in Plutarch. Acta of the IVth International Congress of the International Plutarch Society (Leuven, July 3-6, 1996), Louvain, Namur, 2000.

Weвb, R., "The Progymnasmata as Practice", in Y. L. Too (ed.), Education in Greek and Roman World, Leiden, 2001, pp. 289-316.

Whitmarsh, T., "Alexander's Hellenism and Plutarch's Textualism”, CQ, 52.1 (2002), pp. 174-92.

Greek Literature and the Roman Empire. The Politics of Imitation, Oxford, 2001. 